\title{
Effect of polycarboxylate and polyarylate surfactants on corrosion of the steel reinforcement embedded in the concrete.
}

\author{
Linar Talipov* and Evgeny Velichko \\ Moscow State University of Civil Engineering, Yaroslavskoe shosse, 26, Moscow, 129337, Russia
}

\begin{abstract}
We considered the possibility to inhibit the corrosion of the steel reinforcement embedded in the concrete using different polymeric surfactants, when paired with the passivating and plasticizing chemical additives. Previously [1] the authors proposed the method to form the protective films on the surface of the steel reinforcement embedded in concrete using the polycomponent anticorrosion naphthalene sulfonate superplasticizer based additives. The results of further surveys provided in this article proved, that under the special conditions the polyarylate and polycarboxylate surfactants are capable to keep the steel reinforcement in the passive state in presence of chlorine ions. This is especially relevant, considering the fact, that the polymer additives intended for plasticization of concrete are more widely used for the manufacturing of the monolithic and prefabricated reinforced concrete structures. In the same time Deicing agents having in its composition chlorine ions, are widely used for deicing of roads in different countries. Chlorine ions adversely affect the reinforcement of concrete artificial structures in transport. the corrosion of metals incurs huge losses, the global cost is $\$ 2.5$ trillion, equivalent to $3.4 \%$ of world gross domestic product (GDP) for 2013[2]. In 1993, the United States spent 20 billion dollars on the repair of reinforced concrete bridges only because of the impact of chlorides[3].
\end{abstract}

\section{Introduction}

Corrosion of the reinforcement is one of the reasons for degradation of quality and destruction of the reinforced concrete structures. Corrosion of the reinforcement is a common defect, which in case of the best scenario, results in expensive repair, reconstruction or decommissioning of the construction object, and, in the worst scenario, leads to the local or progressive destruction. So, delaying the moment of corrosion activation in the steel reinforcement embedded in the concrete under the aggressive medium is the urgent goal. The indicated problem is the most important for the bridge superstructures, where the de-icing chlorine-containing agents are used, which result in chloride corrosion.

\footnotetext{
* Corresponding author: nakifulu@mail.ru
} 


\section{Methods}

To define the degree of the surfactants protective ability when applied to the steel reinforcement embedded in the concrete, we simulated the conditions close to the conditions of the chloride corrosion. We designed 'B25' concrete with the compressive strength conforming to GOST 25192-2012 (Concretes. Classification and general technical requirements) and with a slump test of $16-20 \mathrm{~cm}$. according to GOST 10181-2014 (Concrete mixtures. Methods of testing). The concrete mixtures were poured into the 40x40x160 moulds, and compacted. Clean, polished to a metallic luster, $5 \mathrm{~mm}$ grade steel reinforcement was installed into the mold before placement of concreet. The samples were hardened under normal conditions within 28 days. Then, within 6 months, these samples were alternately wetted and dried, then from time to time opened for visual inspection of the corroded area of the reinforcement. We prepared three series of samples for each combination of additives. The trials were carried out in accordance with GOST 31383-2008 (Protection against corrosion of concrete and reinforced concrete constructions. Test methods) the only difference - we used the samples with fewer dimensions - and assessment was close to the qualitative measure, which is admissible within the format of the performed survey. To determine the impact level of the polycarboxylate and polyarylate surfactants, we used our model of the anticorrosion additive for the concrete, and particularly: surfactants ${ }^{1}+$ surfactants $^{2}+\mathrm{NaNO}_{2}$. The specified model gives maximum strong inhibition effect as one of the surfactants is applied to the steel reinforcement due to competitive adsorption of two surfactants on reinforcement. $\mathrm{NaNO}_{2}$ has been considered as an effective corrosion inhibitor for reinforcing steel [4-7]. Upon the survey results [8-10], the impact level of the main inhibition component $\left(\mathrm{NaNO}_{2}\right)$ of the model is assessed to be $80 \%$. It is obvious that the remaining $20 \%$ account to the organic ingredients, which ensure stable passive state of the steel reinforcement for a longer period, thus increasing the life of structures.

We used portland cement (CEM II A-S 32.5R GOST R 57293-2016/EN 197-1:2011 (Common cements. Specifications)) manufactured by 'Mikhailovstsement' as the binding agent for preparing the concrete. Mineral and chemical compositions of the cement clinker of this portland cement are provided in Table 1 and Table 2. The coarse aggregate for the concrete was represented by a chip with a size of 5-20 mm, rinsed with running water and dried prior to batching; and fine aggregate was represented by a medium-grained concrete sand, piped water.

Table 1. Mineral compositions of the cement clinker

\begin{tabular}{|l|l|l|l|}
\hline $\mathrm{C}_{3} \mathrm{~S}(\%)$ & $\mathrm{C}_{2} \mathrm{~S}(\%)$ & $\mathrm{C}_{3} \mathrm{~A}(\%)$ & $\mathrm{C}_{4} \mathrm{AF}(\%)$ \\
\hline $62.7 \pm 3.0$ & $12.6 \pm 2.2$ & $8.2 \pm 1.3$ & $12.7 \pm 0.6$ \\
\hline
\end{tabular}

Table 2. Chemical compositions of the cement clinker, $\%$.

\begin{tabular}{|l|l|l|l|l|l|l|}
\hline $\begin{array}{l}\text { Calcium } \\
\text { oxide }\end{array}$ & $\begin{array}{l}\text { Silicon } \\
\text { oxide }\end{array}$ & $\begin{array}{l}\text { Aluminium } \\
\text { oxide }\end{array}$ & $\begin{array}{l}\text { Iron } \\
\text { oxide } \\
\text { (III) }\end{array}$ & $\begin{array}{l}\text { Magnesium } \\
\text { oxide }\end{array}$ & $\begin{array}{l}\text { Sulfur } \\
\text { Oxide } \\
\text { (IV) }\end{array}$ & $\begin{array}{l}\text { Alkaline oxides } \\
\text { (in terms of } \\
\text { Na2O) }\end{array}$ \\
\hline $65.46 \pm 0.34$ & $20.87 \pm 0.55$ & $5.81 \pm 0.47$ & $4.26 \pm 0.28$ & $1.78 \pm 0.36$ & $0.76 \pm 0.53$ & $0.66 \pm 0.06$ \\
\hline
\end{tabular}

As the surfactants, we used C-3 naphthalene sulfonate superplasticizer from Russian manufacturer as well as the polycarboxylate and polyarylate superplasticizer from Russian, Chinese, Turkish and German manufacturers. In total, 13 different surfactants were provided for the survey. Corrosion process was activated with $\mathrm{CaCl}_{2}$ added to the concrete mixtures with the tempering water during its preparation. 


\section{Results}

When calcium chloride is added with the tempering water, chlorine ions become partially bound, so we set the goal to determine the percentage of $\mathrm{CaCl}_{2}$, when the reinforcement embedded in concrete starts to corrode. The papers [11-13] point to various factors of chloride corrosion including those, which depend on mineral or chemical content of clinker, amount of added chlorides, physically or chemically bound chlorides, processes, when chlorides pass from one binding form to another, hardening conditions, etc. The work [12] indicates that maximum percentage of $\mathrm{Cl}$ ions in the alite, when the steel reinforcement is not apt to corrosion is $1.29 \%$ and $0.64 \%$ for concrete with the water-cement ratio of 0.5 and 0.6 , respectively. By interpolating between the values of the water-cement ratios $=0.5$ and 0.6 of the studied mixtures (water-cement ratio $\approx$ Table 3 ), we defined, that maximum percentage of $\mathrm{Cl}$ ions in the alite high alumina portland cement, when the steel reinforcement is not apt to corrosion is $0.9 \%$. Amount of added $\mathrm{Cl}$ ions were assumed equal in all surveys $-1.504 \%$ that is $2.35 \%$ of cement mass expressed in terms of calcium chloride. Under the stated percentage of the calcium chloride, reinforcement must be corroded, if the inhibition ingredients are not added together with $\mathrm{CaCl}_{2}$.

The inhibitor - sodium nitrite $\left(\mathrm{NaNO}_{2}\right)$ being the component of the studied formula of the anti-corrosion system Surfactants $1+$ Surfactants $2+\mathrm{NaNO}_{2}$ - is capable to keep the steel in the passive state in the presence of chloride ions. In addition to its main designated purpose which is the protection of steel reinforcement against corrosion, sodium nitrite has additional effects such as increase of the protective properties of the concrete in case of strong carbonization, a decrease of its permeability and moreover, we should note its availability and cost efficiency. Its protection mechanism and value of the critical concentration of chlorine ions under which nitrite ions are not capable to keep or transfer the reinforcement steel to a passive state and which is $0.3 \% \mathrm{~mol} / \mathrm{l}$ are given in the paper [8]. For the purpose of the study, we simulated consciously the severe conditions using concentration of $\mathrm{Cl} \approx 0.75 \mathrm{~mol} / \mathrm{l}$ in the tempering water. With a glance to the results of the studies [10], we assumed that inhibition of corrosion of steel with nitrite ions is obvious, when the percentage of $\mathrm{NaNO}_{2}$ is equal or exceeds the percentage of $\mathrm{CaCl}_{2}$. Impact of the inhibitor contained in the studied system can be limited by taking sodium nitrite in the percentage $0.85 \%$ from the content of calcium chloride that amounts $2.0 \%$ of the cement mass.

We defined the range of the surfactants in Surfactants ${ }^{1}+$ Surfactants $^{2}+\mathrm{NaNO}_{2}$ formula using the most widely spread superplasticizers available in the market. The key feature of two surfactants is the difference of their adsorption capacities. However, the adsorption capacity of one surfactant type shall be significantly higher than the capacity of the other type of surfactant. Efficient quantitative evaluation of differences between the adsorption degrees is not defined until this moment. However, it is obvious, that the significant effect can be obtained, when more active surfactant completely supersedes the other one on the surface of the cement particles in solid phases and the superseded surfactant completely remains in the liquid phase. However, at the same time, the second surfactant shall have the adsorption ability sufficient for steel adsorption. It is obvious that any surfactant used for plasticization of the concrete mixture can be taken for adsorption on steel. The C-3 superplasticizer was chosen as an active surfactant. Its adsorption capacity is based on chemisorption of C-3 molecules, which react with minerals of clinker, forming the solid organo-mineral phases with covalent links. The energy of the link of one C-3 functional group with minerals of the clinker is higher than the energy of polymer superplasticizers [14]. Upon the results of numerous studies [9, 15], desorption of the superplasticizer, which is linked with the surface minerals of the particles of clinker, does not exceed 5\%. Studies of adsorption of superplasticizers with use of different materials prove that the adsorption 
capacity on the cement increases to the specific limit in proportion to its percentage. When the percentage of the superplasticizer is $0.9 \ldots 1 \%$, there is a formation of the layer on cement particles on the surface as well as the formation of hydrate phases of the monomolecular adsorption layer, which is significantly dependent on the mineral content of the clinker component. Further increase of the content of the superplasticizer results in the formation of the polymolecular adsorption layer and significant reduction of speed of adsorption [9]. The studies defined, that to provide formation of the relatively stable polymolecular layer on the surface of the cement particles of the most active superplasticizer, its content shall be $2.1 \%$ from cement mass, as under this conditions, less active superplasticizer is completely superseded in the liquid phase.

As less active surfactants, we selected 13 different polycarboxylate ether-based superplasticizers and polyarylates. Considering the fact, that all surfactants will remain in the liquid phase, this model does not require classifying them. Surfactant concentrations were selected individually for each of them in accordance with the recommendations of the manufacturer. The additives in two concentrations (minimum and maximum) recommended by the manufacturer were used for the mixtures 4 - 11 inclusive (Table 3) without making preliminary tests. Maximum concentrations recommended by the manufacturer were used for the mixtures 12 - 16 (Table 3) without making preliminary tests too.

Table 3. Composition of concrete

\begin{tabular}{|c|c|c|c|c|c|c|c|c|c|}
\hline \multirow[t]{3}{*}{ No. } & \multirow[t]{3}{*}{ Name } & \multicolumn{8}{|c|}{ Content } \\
\hline & & \multicolumn{4}{|c|}{ additive, cement weight percentage } & \multicolumn{4}{|c|}{$\begin{array}{l}\text { Number of materials per } 1 \mathrm{~m}^{3} \text { of } \\
\text { concrete, } \mathrm{kg}\end{array}$} \\
\hline & & 峁 & 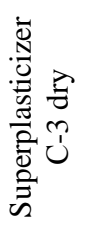 & 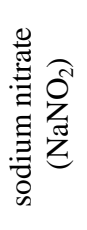 & 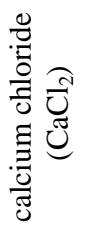 & $\begin{array}{l}\overrightarrow{\tilde{\Xi}} \\
\text { ठ․ }\end{array}$ & 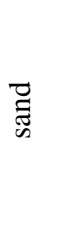 & ్ㅠㅇ & $\begin{array}{l}\overline{\bar{v}} \\
\bar{\pi} \\
3\end{array}$ \\
\hline 1 & - & - & - & - & 2,35 & \multirow{2}{*}{382} & \multirow{2}{*}{516} & \multirow{2}{*}{1265} & \multirow{2}{*}{215} \\
\hline 2 & - & - & - & 2,0 & 2,35 & & & & \\
\hline 3 & - & - & 2,1 & 2,0 & 2,35 & \multirow{15}{*}{276} & \multirow{15}{*}{585} & \multirow{15}{*}{1265} & \multirow{15}{*}{155} \\
\hline \multirow{2}{*}{$\begin{array}{l}4 \mathrm{~A} \\
4 \mathrm{~B}\end{array}$} & \multirow{2}{*}{$\mathrm{PCE}_{1(\mathrm{l})}$} & 0,5 & 2,1 & 2,0 & 2,35 & & & & \\
\hline & & 1,1 & 2,1 & 2,0 & 2,35 & & & & \\
\hline \multirow{2}{*}{$\begin{array}{l}5 \mathrm{~A} \\
5 \mathrm{~B}\end{array}$} & \multirow{2}{*}{$\mathrm{PCE}_{2(\mathrm{I})}$} & 0,5 & 2,1 & 2,0 & 2,35 & & & & \\
\hline & & 1,0 & 2,1 & 2,0 & 2,35 & & & & \\
\hline $6 \mathrm{~A}$ & \multirow{2}{*}{$\mathrm{PCE}_{3(1)}$} & 0,6 & 2,1 & 2,0 & 2,35 & & & & \\
\hline $6 \mathrm{~B}$ & & 1,1 & 2,1 & 2,0 & 2,35 & & & & \\
\hline $7 \mathrm{~A}$ & \multirow{2}{*}{$\mathrm{PCE}_{4(\mathrm{l})}$} & 0,4 & 2,1 & 2,0 & 2,35 & & & & \\
\hline $7 \mathrm{~B}$ & & 1,1 & 2,1 & 2,0 & 2,35 & & & & \\
\hline \multirow{2}{*}{$\begin{array}{l}8 \mathrm{~A} \\
8 \mathrm{~B}\end{array}$} & \multirow{2}{*}{$\mathrm{PCE}_{5(\mathrm{l})}$} & 0,3 & 2,1 & 2,0 & 2,35 & & & & \\
\hline & & 0,8 & 2,1 & 2,0 & 2,35 & & & & \\
\hline \multirow{2}{*}{$\begin{array}{l}9 \mathrm{~A} \\
9 \mathrm{~B}\end{array}$} & \multirow{2}{*}{$\mathrm{PCE}_{6(\mathrm{I})}$} & 0,5 & 2,1 & 2,0 & 2,35 & & & & \\
\hline & & 1,3 & 2,1 & 2,0 & 2,35 & & & & \\
\hline \multirow{2}{*}{$\begin{array}{l}10 \mathrm{~A} \\
10 \mathrm{~B}\end{array}$} & \multirow{2}{*}{$\mathrm{PCE}_{7(\mathrm{l})}$} & 0,5 & 2,1 & 2,0 & 2,35 & & & & \\
\hline & & 1,3 & 2,1 & 2,0 & 2,35 & & & & \\
\hline
\end{tabular}




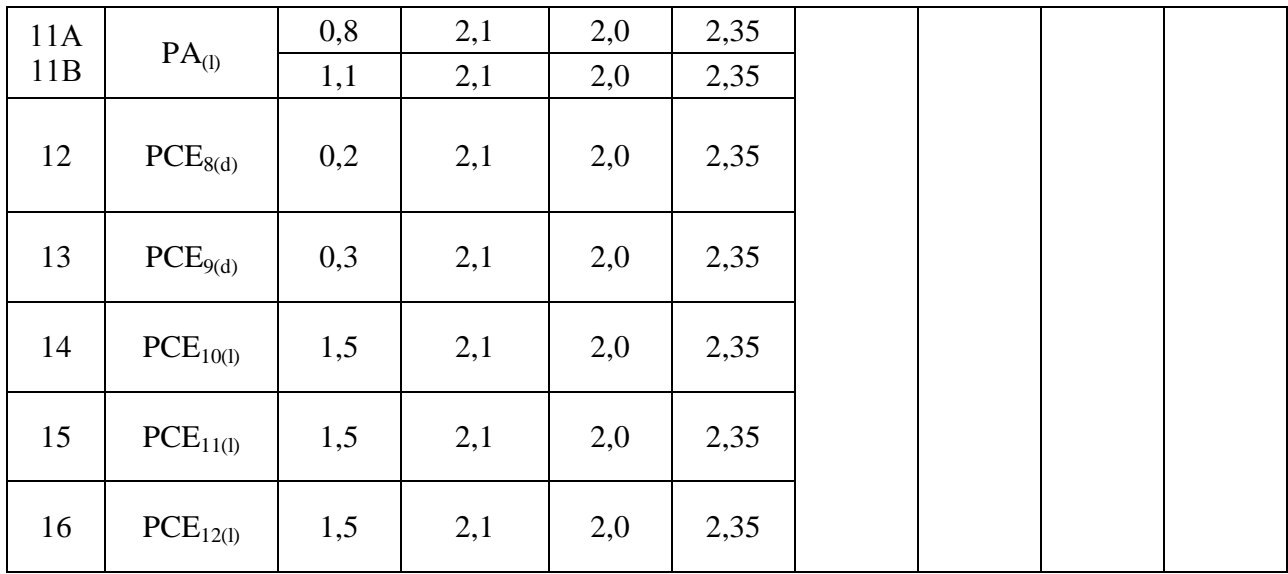

* - (l) and (d) polymers in liquid and dry form, respectively.

Table 4 demonstrates the protection capability of the inhibitors included in the studies formula of Surfactants ${ }^{1}+$ Surfactants ${ }^{2}+\mathrm{NaNO}_{2}$ anti-corrosion system. The assessment was made by analyzing the relative area of the corroded zones of the reinforcement. Hydrogen value was measured using the method of acid-base indication of phenolphthalein and indigo carmine and this value was equal for all samples and amounted 12.

Table 4. Results of the evaluation of the protective ability of the formula of the anti-corrosion system: Surfactants ${ }^{1}+$ Surfactants $^{2}+\mathrm{NaNO}_{2}$.

\begin{tabular}{|c|c|c|c|}
\hline No. & Composite additives & Condition of the reinforcement after opening & $\begin{array}{c}\text { Protective } \\
\text { ability Z, } \\
\%\end{array}$ \\
\hline 1 & without additives & $\begin{array}{l}\text { Corrosion on all samples. Pit corrosion, spots of } \\
\text { corrosion near the end face, individual spots of } \\
\text { corrosion with dimensions up to } 20 \times 6 \text { located } \\
\text { locally along the whole surface. }\end{array}$ & 72,29 \\
\hline 2 & $\left(\mathrm{NaNO}_{2}\right)$ & $\begin{array}{l}\text { Corrosion is visible on two samples. Pit } \\
\text { corrosion, spots of corrosion with dimensions } \\
\text { up to } 25 \times 20 \text { located locally along the whole } \\
\text { surface. }\end{array}$ & 72,98 \\
\hline 3 & $(\mathrm{C}-3)+\left(\mathrm{NaNO}_{2}\right)$ & $\begin{array}{l}\text { Corrosion is visible on one sample. Individual } \\
\text { spots of corrosion located locally along the } \\
\text { whole surface. }\end{array}$ & 95,00 \\
\hline $4 \mathrm{~A}$ & $(\mathrm{C}-3)+\left(\mathrm{NaNO}_{2}\right)+\left(\mathrm{PCE}_{1}\right)$ & $\begin{array}{l}\text { Corrosion is visible on one sample. Corrosion } \\
\text { on one end face of the reinforcement. }\end{array}$ & 99,90 \\
\hline 4B & $(\mathrm{C}-3)+\left(\mathrm{NaNO}_{2}\right)+\left(\mathrm{PCE}_{1}\right)$ & $\begin{array}{l}\text { Corrosion on all samples. Individual spots of } \\
\text { corrosion located locally along the surface. }\end{array}$ & 96,55 \\
\hline $5 \mathrm{~A}$ & $(\mathrm{C}-3)+\left(\mathrm{NaNO}_{2}\right)+\left(\mathrm{PCE}_{2}\right)$ & Reinforcement is free from corrosion. & 100,00 \\
\hline $5 \mathrm{~B}$ & $(\mathrm{C}-3)+\left(\mathrm{NaNO}_{2}\right)+\left(\mathrm{PCE}_{2}\right)$ & Reinforcement is free from corrosion. & 100,00 \\
\hline $6 \mathrm{~A}$ & $(\mathrm{C}-3)+\left(\mathrm{NaNO}_{2}\right)+\left(\mathrm{PCE}_{3}\right)$ & Reinforcement is free from corrosion. & 100,00 \\
\hline $6 \mathrm{~B}$ & $(\mathrm{C}-3)+\left(\mathrm{NaNO}_{2}\right)+\left(\mathrm{PCE}_{3}\right)$ & Reinforcement is free from corrosion. & 100,00 \\
\hline $7 \mathrm{~A}$ & $(\mathrm{C}-3)+\left(\mathrm{NaNO}_{2}\right)+\left(\mathrm{PCE}_{4}\right)$ & Reinforcement is free from corrosion. & 100,00 \\
\hline $7 \mathrm{~B}$ & $(\mathrm{C}-3)+\left(\mathrm{NaNO}_{2}\right)+\left(\mathrm{PCE}_{4}\right)$ & $\begin{array}{l}\text { Corrosion is visible on one sample. One spot of } \\
\text { corrosion on the surface of the reinforcement. }\end{array}$ & 97,95 \\
\hline $8 \mathrm{~A}$ & $(\mathrm{C}-3)+\left(\mathrm{NaNO}_{2}\right)+\left(\mathrm{PCE}_{5}\right)$ & $\begin{array}{l}\text { Corrosion is visible on one sample. One spot of } \\
\text { corrosion on the surface of the reinforcement. }\end{array}$ & 99,77 \\
\hline $8 \mathrm{~B}$ & $(\mathrm{C}-3)+\left(\mathrm{NaNO}_{2}\right)+\left(\mathrm{PCE}_{5}\right)$ & Reinforcement is free from corrosion. & 100,00 \\
\hline 9A & $(\mathrm{C}-3)+\left(\mathrm{NaNO}_{2}\right)+\left(\mathrm{PCE}_{6}\right)$ & Reinforcement is free from corrosion. & 100,00 \\
\hline 9B & $(\mathrm{C}-3)+\left(\mathrm{NaNO}_{2}\right)+\left(\mathrm{PCE}_{6}\right)$ & Reinforcement is free from corrosion. & 100,00 \\
\hline
\end{tabular}




\begin{tabular}{|c|c|l|c|}
\hline $10 \mathrm{~A}$ & $(\mathrm{C}-3)+\left(\mathrm{NaNO}_{2}\right)+\left(\mathrm{PCE}_{7}\right)$ & Reinforcement is free from corrosion. & 100,00 \\
\hline $10 \mathrm{~B}$ & $(\mathrm{C}-3)+\left(\mathrm{NaNO}_{2}\right)+\left(\mathrm{PCE}_{7}\right)$ & Reinforcement is free from corrosion. & 100,00 \\
\hline $11 \mathrm{~A}$ & $(\mathrm{C}-3)+\left(\mathrm{NaNO}_{2}\right)+\left(\mathrm{PCE}_{8}\right)$ & Reinforcement is free from corrosion. & 100,00 \\
\hline $11 \mathrm{~B}$ & $(\mathrm{C}-3)+\left(\mathrm{NaNO}_{2}\right)+\left(\mathrm{PCE}_{8}\right)$ & $\begin{array}{l}\text { Very small corrosion, hardly visible with } \\
\text { human eye. }\end{array}$ & 99,90 \\
\hline 12 & $(\mathrm{C}-3)+\left(\mathrm{NaNO}_{2}\right)+\left(\mathrm{PCE}_{9}\right)$ & $\begin{array}{l}\text { Very small corrosion, hardly visible with } \\
\text { human eye. }\end{array}$ & 99,90 \\
\hline 13 & $(\mathrm{C}-3)+\left(\mathrm{NaNO}_{2}\right)+\left(\mathrm{PCE}_{10}\right)$ & $\begin{array}{l}\text { Corrosion is visible on one sample. One spot of } \\
\text { corrosion on the surface of the reinforcement. }\end{array}$ & 98,14 \\
\hline 14 & $(\mathrm{C}-3)+\left(\mathrm{NaNO}_{2}\right)+\left(\mathrm{PCE}_{11}\right)$ & $\begin{array}{l}\text { Corrosion is visible on one sample. Pit } \\
\text { corrosion. Two 10x10 mm spots of corrosion } \\
\text { on the surface of the reinforcement. }\end{array}$ & 96,46 \\
\hline 15 & $(\mathrm{C}-3)+\left(\mathrm{NaNO}_{2}\right)+\left(\mathrm{PCE}_{12}\right)$ & $\begin{array}{l}\text { Pit corrosion located on the end face of one } \\
\text { sample. }\end{array}$ & 97,52 \\
\hline 16 & $(\mathrm{C}-3)+\left(\mathrm{NaNO}_{2}\right)+\left(\mathrm{PCE}_{13}\right)$ & Reinforcement is free from corrosion. & 100,00 \\
\hline
\end{tabular}

\section{Discussion}

It was found out that 6 out of 13 studied polymer-based additives included in the formula of the anti-corrosion system: Surfactant $1+$ Surfactant $2+\mathrm{NaNO}_{2}$ in the approved concentrations demonstrated the protective ability of $5 \%$ and the remaining 7 - demonstrated the protective ability from 1.46 to $4.9 \%$. Additive $\left(\mathrm{C}-3+\mathrm{NaNO}_{2}\right)$ demonstrated the protective ability of 95\%. Considering the fact, that contribution of sodium nitrite, when it is used in line with $\mathrm{C}-3$, is $80 \%$, so the percentage of $\mathrm{C}-3$ in the polymerization mixture is $15 \%$, and the percentage of polymers is up to $5 \%$. In the systems of $(\mathrm{C}-3)+\left(\mathrm{NaNO}_{2}\right)+(\mathrm{PCE} / \mathrm{PA})$ type, $\mathrm{C}-$ 3 additive forms polymolecular layer due to higher speeds of adsorption and energy of links with surface of the particles of clinker minerals and the significant part of this layer is able to desorption and prevents the adsorption of PCE. It is obvious that the desorbed C-3 competes in steel reinforcement adsorption with PCE and chlorine ions by forming a barrier for inhibition of reinforcement corrosion under the effect of sodium nitrite. As expected, sodium nitrite did not demonstrate any positive results, if it is used individually, however, if it is used in line with surfactants, it demonstrates significant synergetic effect and in the range of cases - complete inhibition of corrosion of the steel reinforcement embedded in normal-weight concrete.

Thus, we can conclude that the polycarboxylate and polyarylate surfactants included to the system $(\mathrm{C}-3)+\left(\mathrm{NaNO}_{2}\right)+(\mathrm{PCE} / \mathrm{PA})$ are capable to participate in the inhibition of corrosion of the steel reinforcement embedded in the normal-weight concrete. Determinant factor for the combined application of the plasticizing additives of different nature and with different adsorption abilities is related to their compatibility according to the plasticizing effect.

\section{References}

1. E.G. Velichko, L.N. Talipov, Theoretical and practical aspects of improving the durability of steel reinforcement in transport designs, using passivation and plasticizing chemical additives, IOP Conf. Ser.: Earth Environ. Sci. 90, 012202 (2017)

2. Koch G, Varney J, Thompson N, Moghissi O, Gould M, Payer J, International measures of prevention, application, and economics of corrosion technologies study, Report by NACE international, iii(2016) 
3. Raupach M, Elsener B, Polder R and Mietz J, Corrosion of Reinforcement in Concrete Monitoring, Prevention and Rehabilitation Techniques, p. 336, (2006)

4. G. Sahoo and R. Balasubramaniam, On the corrosion behaviour of phosphoric irons in simulated concrete pore solution, Corros. Sci., 50, 131(2008)

5. J. M. Gaidis, Chemistry of corrosion inhibitors, Cem. Concr. Compos., 26, 181(2004)

6. H. W. Song, V. Saraswathy, S. Muralidharan, C. H. Lee and K. Thangavel, Role of alkaline nitrites in the corrosion performance of steel in composite cements, J. Appl. Electrochem., 39, 15(2009)

7. B. Qiao, R.G. Du, W. Chen, Y. F. Zhu and C.J. Lin, Effect of $\mathrm{NO}_{2}{ }^{-}$and $\mathrm{Cl}^{-}$on the corrosion behavior of reinforcing steel in simulated concrete pore solutions, Acta Metall. Sin., 46(2), 245-250(2010)

8. E.I. Tupikin, E.E. Platonova, Increasing metals capacity for passivation using complex additives (Publisher Association building universities, Moscow, 2009)

9. V.G. Batrakov, Modified concrete. Theory and practice. - second edition., revised and updated (Moscow, 1998)

10. V.B. Ratinov, T.I. Rosenberg, Concrete admixtures (Stroyizdat, Moscow, 1989)

11. N.K. Rosenthal, V.F. Stepanova, G.V. Chechnyi, About maximum admissible content of chlorides in concret, Stroitel'nye Materialy [Construction materials], 1-2, 8285(2017)

12. N.K. Rosenthal, V.F. Stepanova, G.V. Chechnyi, Chlorides in concrete and their impact on the development of corrosion of steel reinforcement, Promyshlennoe $i$ grazhdanskoe stroitel'stvo [Industrial and Civil Engineering], 1, 92-96(2017)

13. V. Kumar, Ramesh Singh, M. A. Quraishi, Study on Corrosion of Reinforcement in Concrete and Effect of Inhibitor on Service Life of RCC, J. Mater. Environ. Sci., 4 (5), 726-731(2013)

14. P. I. Yukhnevsky, On the mechanism of plasticizing cement compositions with additives, Construction science and technology: scientific and technical journal, 1-2, 64-69(2009)

15. A.I. Vovk, Some features of the application hyper plasticizer, Concrete technology, $\mathbf{5}$, 18-19(2007) 